\title{
Mathematics as a Universal Language of Philosophy in the Interpretation of D. Venevetinov and V. Odoevsky
}

\author{
Anna V. Martseva \\ Peoples' Friendship University of Russia (RUDN University) \\ 6 Miklukho-Maklaya St., Moscow, 117198, Russian Federation \\ martseva@mail.ru
}

\begin{abstract}
The paper attempts to analyze the problem of the development of a philosophical language in Russia on the basis of one of the conceptual options for its solution proposed by two leaders of the "Society of Wisdom-Loving" (Obshchestvo lyubomudriya), Dmitry Venevitinov and Vladimir Odoevsky. Despite the existing romantic affirmation of the principle of "nationality" (narodnost') in philosophy, science and art, Venevitinov and Odoevsky assume that in theory, the development of the philosophical language should not be confined to the national language only. They are most interested in the universalist concepts of the philosophical language, which in the 1920s are represented by romantic natural philosophy and are connected to the concept of "mathesis". VenevitinovOdoevsky's identification of the natural philosophical sources of solving the problem of the philosophical language transforms the current perception of the Russian philosophical romanticism of the 1820 s as consistent Schellingianism, since, in this case, it is a matter of the conscious recycling of the Okenian version of natural philosophy.
\end{abstract}

Keywords-Philosophical language; Russian philosophical romanticism; V. Odoevsky, D. Venevitinov; Mathesis; "Society of Wisdom-Loving"

\section{INTRODUCTION}

A number of reasons can account for the search for a new philosophical language becoming one of the most important areas of Russian philosophical thought in the 1820s. First, by this time, philosophy has already proved to be directly dependent on the linguistic debates of this period, which revolved around the problem of a national secular language reflecting the national and cultural identity of the Russian people. Second, the formulation of the problem of a new philosophical language was initiated by the representatives of Romanticism - a young trend in Russian philosophical thought that sought to create the maximum distance between itself and the prevailing philosophical tradition - enlightenment. This distance came into view not only in terms of its meaning, but also formally, including at the language level. Thirdly, the philosophy of Romanticism in Russia (like the philosophy of the Enlightenment era) was shaped based primarily on Western European Romanticist sources [1], which had to be translated into Russian, which required at least a serious revision of the

About the author:

Martseva Anna - CSc in Philosophy, Assistant at Department of History of Philosophy, Faculty of Humanities and Social Science, Peoples' Friendship University of Russia (RUDN University), 6 Miklukho-Maklaya St., Moscow, 117198, Russian Federation

E-mail: martseva@mail.ru. conceptual-discursive apparatus of the Russian philosophy of the period. In the so-called "Society of Wisdom-Loving" (Obshchestvo lyubomudriya) (1823-1825), a highly representative phenomenon of Russian circular philosophy, a new "distinctive" philosophy was developed that suggested a change in its language.

\section{II. "SOCIETY OF WISDOM-LOVING" AND THE PROJECT OF PHILOSOPHICAL LANGUAGE}

Two leaders of the circle - Vladimir F. Odoyevsky and Dmitry V. Venevitinov consider the use of mathematics as a universal language of philosophy as one of the most promising possibilities for solving the language problem. It is important to note that the views of Odoyevsky and Venevitinov on philosophy during this period were very similar. Relying on a very limited range of sources (this primarily concerns the fragmentary reception of individual texts by F.W.J. Schelling, L. Oken and the German Romanticists), they believed that philosophy should claim the perfect form. Consequently, the perfect form presupposes a perfect language, one that will not depend on the cultural, historical, linguistic, emotional and other characteristics of the subject. The philosophers wanted a universal language for absolute philosophy. All of the existing strategies for the development of the Russian language to the level of the "metaphysical", according to Pushkin's apt definition, could not meet this requirement of universality, since any verbal, the more lively language, is already inherently historical, changeable. Therefore, the philosophers concentrated their researches on the sphere of the non-verbal language.

\section{MATHEMATICAL PHILOSOPHY AND MATHESIS IN THE CONTEXT OF UNIVERSAL LANGUAGE}

In the field of view of Venevitinov and Odoyevsky, mathematics as a perfect language already acquired by mankind does not arise simply accidentally. This idea was borrowed from very specific sources - the works of Lorenz Oken and his followers that were available to them. There are several surviving translation fragments, as well as letters in which Venevitinov and Odoyevsky, discussing the possibility of using mathematics as a universal language of philosophy, reveal some of these sources: first is the "Theosophy" of Oken, 
in which the idea of mathematics holds the fundamental place, and secondly, the numerous articles from the Oken's natural philosophical journal "Isis" [2], [3], [4]. Particular attention should be paid to the interpretation by Venevitinov of the journalistic polemics between J. J. Wagner and B.H. Blasche. For Wagner, mathematics is the purest science that includes the law of universe. Blasche, in turn, upholds the primacy of philosophy in relation to mathematics. This discussion certainly transforms the views of the philosophers towards greater realism. The original utopian project, as seen by, for example, Odoyevsky, was an attempt to continue the search for a universal language in the spirit of the combinatorics of $\mathrm{R}$. Lullius and the developments of Leibniz. Mathematics was represented as a ready-made tool that could be used in philosophy. Later Odoyevsky is further developing the idea of universal language by analyzing the other strategies for the development of a language in the spirit of the mystical traditions (the "inner language") of J. Pordage, L.C. de SaintMartin and F.X. von Baader, as well as the romantic concept of creating an "ideal language" through the synthesis of philosophy and the arts [5], [6], [7]. Despite the fact that both Venevitinov and Odoyevsky were the masterminds behind the development of the problem of universal language, it is Venevitinov who is more inherently interested in mathematical philosophy. By critically analyzing an extract of the WagnerBlashe dispute, the philosopher draws conclusions on the possibility of using mathematical language as a philosophical language. Venevitinov denies Wagner's main point that "mathematics is the only common science, the only philosophy, and all the other sciences are only the application of this exceptionally pure science, application in the spiritual or physical sphere" [8]; in his opinion, mathematics may be regarded as the main organ of all sciences that has its own agenda and origin. Nevertheless, mathematics is neither the science of all sciences nor a philosophy, since it does not satisfy the conditions that Schelling imposes on the "Idealist" (the way Venevitinov apparently refers to the "System of Transcendental Idealism"): as a higher science, mathematics must fall under the "science of the absolute idea (absolute zero) and the science of manifestation of this zero." It cannot fulfill this requirement, since in both cases, it turns out to be the science of the finite world. At the same time, Venevitinov agrees with the thesis that "the mathematical expression of an idea is the purest and most common one, and that mathematics assessed from this point of view is actually a language of ideas, a language of the mind" [8], and in this sense can act as a language of philosophy. In his letter to Koshelev, Venevitinov initially characterizes this idea as "too passionate," but does not lose interest in it. The final shaping of the philosophical language, according to Venevitinov, is a matter for the future.

\section{CONCLUSION}

In this way, in the example of the polemics of Wagner and Blashe, who were actually representatives of the same philosophical school of thought, it was clear that mathematics could not be thought of as a means of philosophical selfexpression, as it claimed at least the status of being an independent science, and, as a maximum, the status of a science of sciences instead of philosophy. In addition, the philosophers needed to clarify exactly which type of mathematics they were talking about, because mathematics as a science is not something perfect and frozen, but is in a state of movement and transformation. Obviously, it was still about philosophical mathematics in its natural and philosophical Okenian version as a mathesis. Solving the problem of the philosophical language is extremely interesting because it shows that in many cases, the Russian Romanticists were followers of Oken, not Schelling, contrary to the established research classification.

\section{REFERENCES}

[1] A. Koyré, Philosophy and National Problem in Russia at the Beginning of the 19th Century. Moscow, 2003. (In Russian).

[2] Blasche B.H. Doch vielleicht Philosophie und nichn Mathematik. Isis. 1818. Bd. 1. S. $152-155$.

[3] Blasche B.H. Noch etwas über Philosophie und Mathematik, in ihrem gegenseitigen Verhältnisse. - Zur endlichen Verständigung mit Herr J. [J]. Wagner. Isis. 1820. Bd. 1. Heft 6. S. 310-314.

[4] [Blasche B.H. Zur Antwort auf J.J. Wagner Aufsatz: Die Verklärung der Wissenschaft. Isis. 1821. Bd. 1. Heft 4. S. 346-350.

[5] N. Cornwell, V.F. Odoevsky. His Life, Time and Milieu. Bloomsbury Publishing, 2015.

[6] M.Ya. Struminsky, "V.F. Odoyevsky and his pedagogical ideas", in Odoyevsky V.F. Selected Pedagogical Writings. Moscow, 1955. (In Russian).

[7] P.N. Sakulin, From the history of Russian idealism: V.F. Odoyevsky as a thinker and writer, vol. 1, parts 1-2. Moscow, 1913. (In Russian).

[8] Venevitinov D. The complete works in 1 vol. Moscow, 1934. P. 258-259. (In Russian). 